\title{
Implementation of the Water Framework Directive in an Outermost EU Region: The Case of Azores Archipelago
}

\author{
J Virgílio Cruz ${ }^{1, *}$, Dina Pacheco ${ }^{2}$, Sérgio Costa ${ }^{3}$, Carla Melo ${ }^{3}$, Raquel Cymbron ${ }^{2}$, Regina Nogueira $^{4}$ \\ and António G Brito ${ }^{4}$
}

${ }^{1}$ CVARG - Centre of Volcanology and Geological Hazards Assessment Departament of Geosciences, University of Azores, Apartado 1422 9501-801 Ponta Delgada Portugal; ${ }^{2}$ Directorate-Regional for Environment Av. Antero de Quental, 9 C 9500-160 Ponta Delgada Portugal, ${ }^{3}$ SIMBIENTE Açores, Environmental Engineering and Management Lda Rua Azores Parque 102 Edifício 2.1 - Ninho de Empresas Azores Parque 9500-794 Ponta Delgada Portugal; ${ }^{4} I B B$ - Institute for Biotechnology and Bioengineering Centre of Biological Engineering University of Minho Portugal

\begin{abstract}
The Azores Water Plan (AWP) came to force in year 2003 in order to provide a coherent set of measures to protect and enhance water resources in the archipelago. The AWP was developed according to EU Water Framework Directive (WFD) and a close relationship can be found between goals on both documents. The evaluation of results associated to AWP implementation, made possible through a consultation procedure described in the present paper, provides an indirect assessment of the implementation of the WFD in an EU outermost region such as the Azores. The analysis suggests that major constrains to the full implementation of the AWP and WFD are associated with administrative arrangements, reflected in a lack of coordination, as well as adequate funding and cost recovery and strategies for public participation and information provision. Instead, water quality monitoring is already fully operational showing a strong relationship between science and water policy.
\end{abstract}

Keywords: Water resources, EU Water Framework Directive, Regional water planning, Azores, EU outermost regions, Water management.

\section{INTRODUCTION}

The Water Framework Directive (WFD; Directive $\mathrm{n}^{\circ}$ 2000/60/CE) is the main EU water policy instrument. As one of a new generation of EU Directives, it sets broad policy objectives, and is associated with a rather demanding implementation strategy. The WFD can be considered as one of the most advanced water regulations in the world, and is innovative in its spatial approach to the protection and management of river basins, especially due to its recognition of the emphasis placed on aquatic ecosystems [1, 2]. The WFD is also innovative as it stresses the increasing role of stakeholders in the decision making process, it is consistent with a shift from a government to a governance based framework [3-6].

The challenges associated to WFD implementation are multiple. Two examples are the shift of administrative responsibilities to a watershed focus [7] and the cost- effectiveness analysis needed in the decision support processes [8]. Concerns about the delivery of the WFD's goals therefore remain $[6,9]$, The first progress report about the implementation of the WFD was issued in 2007 and shows that performance is heterogeneous between member states [10].

The Azores archipelago is one of the seven outermost regions of the European Union. Located in the

*Address correspondence to this author at the CVARG - Centre of Volcanology and Geological Hazards Assessment Departament of Geosciences University of Azores Apartado 1422 9501-801 Ponta Delgada Portugal; Tel. +351 296650147; Fax. +351 296650142; E-mail: jvc@uac.pt

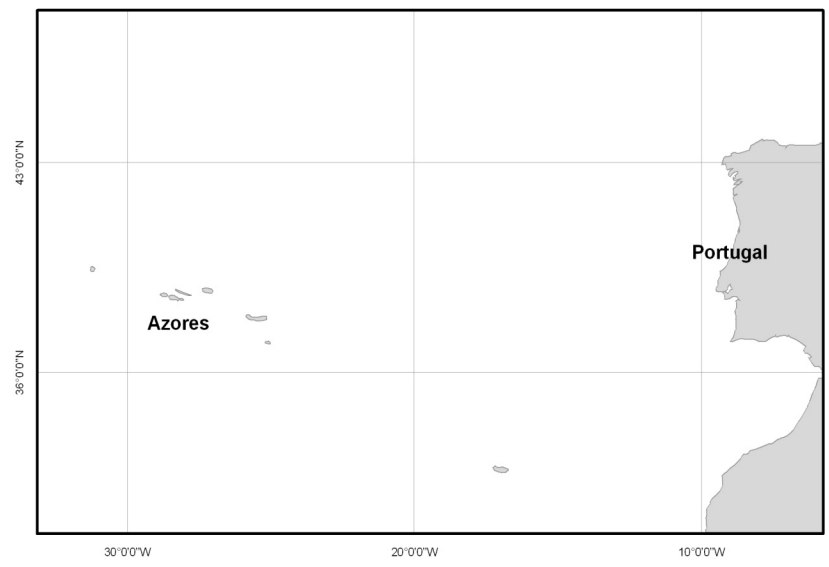

Fig. (1). Location of the Azores archipelago in the NorthAtlantic Ocean, about $1500 \mathrm{~km}$ from Portugal mainland.

North Atlantic, about $1500 \mathrm{~km}$ from Portugal mainland, the archipelago is composed of nine volcanic islands, spread along a NW trending strip, about $500 \mathrm{~km}$ long (Fig. 1). It has a total surface area of $2333 \mathrm{~km}^{2}$, but the dispersion and the fragmented character of the territory is shown by the variations in the islands surface area, ranging from 17 to $747 \mathrm{~km}^{2}$. The islands have about 240000 inhabitants, mainly living at São Miguel (54\%) and Terceira (23\%), associated to an irregular distribution of the population, with islands with a density of 28 to 179 inhabitants $/ \mathrm{km}^{2}$ (median $=57$ inhabitants $\left./ \mathrm{km}^{2}\right)$. 
The Azores, as well as the Portuguese Autonomous Region of Madeira, the French overseas departments of Guadeloupe, French Guiana, Martinique and Reunion and the Spanish Autonomous community of the Canary Islands, are outermost regions of the European Union. This status derives from the peripheral position of these regions in relation to the European mainland, which implies a disadvantaged socio-economic setting $[11,12]$. The unique setting of the outermost regions in the overall context of the EU was already recognised in the Amsterdam Treaty by means of a specific article (art. 299(2)). Recently the European Commission issued a communication (COM (2007) 507 final) about the outermost regions strategy, and launched a consultation process about future prospects on this subject [13]. Subsequent communications (COM (2008) 642 final) include a major review of the consultation process results and identify the main guidelines for an outermost regions strategy [14].

With regard to the WFD, the Azores archipelago has specific authority to define its own policies for water resources management and protection. There are some particular pressures relating to sustainability. The specific hydrological regime, characterized by a surface flow of torrential character, as well as the low regulation capacity provided by the aquifers, due to their dimension, are major constrains to sustainable water management. When the WFD came into force, the Azores government started a large multidisciplinary study in order to prepare the Azores Water Plan (AWP), with the aim of providing for the first time background policies to protect and value the water resources in the archipelago, based on a large set of programmes and actions in a ten years time frame [15]. The AWP was prepared with reference to the framework provided by the WFD, relating for example the concept of water bodies and the ecosystems approach to assess water quality.

As the AWP includes quantitative goals, it is possible to evaluate its overall implementation, as well as its interaction with the WFD, and in 2006 a study was ordered by the regional government to do this. Within this paper we (1) present the major guidelines of the AWP, and consider their interrelationships with the WFD; (2) present the methodology and results from the performance assessment of the AWP and, (3) discuss the constraints and difficulties of implementing WFD in an outermost region of the EU.

\section{BACKGROUND INFORMATION ON WATER RESOURCES IN THE AZORES}

\section{Climate}

The average annual precipitation is $1930 \mathrm{~mm}$, ranging in the archipelago between $966 \mathrm{~mm} / \mathrm{yr}$ (Graciosa Island) and $2647 \mathrm{~mm} / \mathrm{yr}$ (Flores Island), exceeding by far the average annual actual evapotranspiration $(581 \mathrm{~mm} / \mathrm{yr})$. The average annual actual evapotranspiration ranges between 502 $\mathrm{mm} / \mathrm{yr}$ (São JorgeIsland) and $632 \mathrm{~mm} / \mathrm{yr}$ (Graciosa Island) [15]. The climate can be considered as marine temperate, which is reflected by the low thermal amplitude, high precipitation, high air humidity and persistent wind, as well as a sharp contrast between a dry season and a colder and wet season. Estimates from the monthly precipitation measurements show that about $75 \%$ of the annual precipitation occurs between October and March [15].

\section{Surface Water}

Surface flow is usually torrential in nature and the river length is usually small. The average annual runoff is 680 $\mathrm{mm} / \mathrm{yr}$, ranging between $134 \mathrm{~mm} / \mathrm{yr}$ (Graciosa Island) and $1371 \mathrm{~mm} / \mathrm{yr}$ (Flores Island). Estimates for the average discharge provided by the AWP show a value equal to $322 \times 10^{6} \mathrm{~m}^{3} / \mathrm{yr}$, with a range between $8 \times 10^{6} \mathrm{~m}^{3} / \mathrm{yr}$ (Graciosa Island) and $1731 \times 10^{6} \mathrm{~m} / \mathrm{yr}$ (São Miguel Island) [15]. The surface area of the 88 inland lakes, spread in most islands with the exception of Santa Maria, Faial, Graciosa and São Jorge, is equal to $9.5 \mathrm{~km}^{2}$, about $0.4 \%$ of the Azores area [15-17]. Two other lakes occur inside volcanic caves (namely at Terceira and Graciosa) and there are also three coastal lakes at São Jorge Island, which are the transition water bodies in the region (in the absence of typical estuarine systems). The volume of water contained in the lakes is estimated at about $9 \times 10 \mathrm{~m}^{3}$, from which $93 \%$ and $5 \%$ corresponds respectively to water bodies at São Miguel and Flores islands. The most voluminous lake is located at São Miguel and contains about $4.8 \times 10^{7} \mathrm{~m}^{3}$.

\section{Groundwater}

Groundwater occurs in two major aquifers systems: (1) the basal aquifer system, which corresponds to freshwater lenses floating on underlying salt water, and (2) in perched-water bodies [18]. Groundwater resources in the archipelago are about $1580 \times 10^{6} \mathrm{~m}^{3} / \mathrm{yr}$, with values ranging from $8.3 \times 10^{6} \mathrm{~m}^{3} / \mathrm{yr}$ (Corvo Island) and $582 \times 10^{6} \mathrm{~m} / \mathrm{yr}$ (Pico Island) [19]. More than 1000 springs and wells are spread all over the archipelago, and in certain areas there are numerous hand-dug wells, which were a traditionally groundwater abstraction system. Specific capacity is on the range of $1.4 \times 10^{-2}-266.7 \mathrm{~L} / \mathrm{s} . \mathrm{m}$, with a median value of $32.3 \mathrm{~L} / \mathrm{sm}$. Transmissivity values also present a large range, with values between $1.7 \times 10^{-5}$ and $4 \times 10^{-1} \mathrm{~m}^{2} / \mathrm{s}$, and a median of $3.7 \times 10^{-2} \mathrm{~m}^{2} / \mathrm{s}$ [19].

\section{Water Quality}

Groundwater chemical composition in the basal aquifer system and in perched-water bodies shows compositional differences [20, 21]. Groundwater salinization is a widespread phenomenon in wells that are drilled in the basal aquifer system, and this process led to well abandonments in several islands, causing severe economical losses [22]. Groundwater pollution due to agricultural activities has also been reported in the majority of the nine islands, especially in the perched-water bodies, as shown by high contents of nitrogen species or microbiology parameters, resulting in some cases in failure to comply with EU and national water quality regulations. The impact of agriculture activity in the water quality of lakes has been widely reported, as a large number of these surface water bodies are eutrophic, leading in certain cases to the seasonal occurrence of algae blooms [23-26].

\section{Water Demand}

About $98 \%$ of the total water demand in Azores results from the exploitation of groundwater resources. Human consumption explains about $56 \%$ of the total water de- 
Table 1. AWP Thematic Areas and Direct (D) / Indirect (inD) Interrelationship with WFD (n.a. - Not Applicable)

\begin{tabular}{|c|c|c|}
\hline Thematic Area & Strategic Guideline & Interrelationship with WFD \\
\hline A1. Water supply & $\begin{array}{l}\text { Improve water offer and promote an adequate water de- } \\
\text { mand management of domestic and economic activities } \\
\text { (mainly agricultural and industrial) }\end{array}$ & $\begin{array}{l}\text { D: art. } 7 \text { (protection of water sources); art. } 10 \text { (pollution } \\
\text { control) inD: art. } 5 \text { (characterization); art. } 11 \text { (measures); } \\
\text { art. } 17 \text { (gw protection) }\end{array}$ \\
\hline A2. Water quality & Protect and improve water quality & $\begin{array}{l}\text { D: art. } 10 \text { (pollution control) inD: art. } 4 \text { (pollution pre- } \\
\text { vention); art.11 (measures); art. } 17 \text { (gw protection) }\end{array}$ \\
\hline A3. Natural resources & $\begin{array}{l}\text { Provide protection to natural resources and especially to } \\
\text { ecosystems of special interest }\end{array}$ & $\begin{array}{l}\text { D: art. } 5 \text { (characterization); art. } 3 \text { (protected areas) inD: } \\
\text { art. } 4 \text { (protected areas); art. } 11 \text { (measures) }\end{array}$ \\
\hline A4. Natural and anthropogenic hazards & $\begin{array}{l}\text { Prevent and mitigate risks associated to flood events } \\
\text { and pollution accidents }\end{array}$ & $\begin{array}{l}\text { D: art. } 10 \text { (pollution control) inD: art. } 11 \text { (measures); art. } \\
17 \text { (gw protection) }\end{array}$ \\
\hline $\begin{array}{l}\text { A5. Land and public hydric domain } \\
\text { management }\end{array}$ & Articulate land management and public hydric domain & $\begin{array}{l}\text { D: art. } 1003 \text { (planning) inD: art. } 4 \text { (management); art. } 5 \\
\text { (characterization) }\end{array}$ \\
\hline $\begin{array}{l}\text { A6. Institutional and normative frame- } \\
\text { work }\end{array}$ & $\begin{array}{l}\text { Reorganize the institutional framework as well as the } \\
\text { normative setting }\end{array}$ & D: art. 3 (administrative arrangements) inD: n.a. \\
\hline A7. Economic and financial framework & Promote economic and financial sustainability & D: art. 9 (costs) inD: art. 5 (characterization) \\
\hline A8. Public participation and information & Promote the information and participation of the public & $\begin{array}{l}\text { D: art. } 14 \text { (participation and information) inD: art. } 8 \\
\text { (monitoring) }\end{array}$ \\
\hline A9. Research \& Development & $\begin{array}{l}\text { Increase the knowledge about water resources in the } \\
\text { Azores }\end{array}$ & $\begin{array}{l}\text { D: art. } 8 \text { (monitoring) inD: art. } 7 \text { (monitoring); art. } 11 \\
\text { (measures) }\end{array}$ \\
\hline
\end{tabular}

mand $\left(15176 \times 10^{3} \mathrm{~m}^{3} / \mathrm{yr}\right)$, while industry and agriculture correspond to about $21 \%$ (respectively $5724 \times 10^{3} \mathrm{~m}^{3} / \mathrm{yr}$ and $\left.5723 \times 10^{3} \mathrm{~m}^{3} / \mathrm{yr}\right)$. According the most conservative scenario presented in the AWP an increase of $28 \%$ is estimated for water demand in the year 2020. This increase is mainly associated to domestic (77\%) and tourism (21\%) demand.

\section{Early Classification of Water bodies}

According to article 5 of the WFD, 71 surface water bodies were delimited, corresponding to 15 rivers, 26 lakes, 3 transition waters and 27 coastal waters [27]. From these surface water bodies, $32 \%$ were classified as being at risk of not achieving good status by 2015, corresponding mainly to lakes, while $31 \%$ are in doubt of not fulfilling the objectives. Regarding the 54 groundwater bodies, it was concluded that none at risk of not meeting the WFD objectives.

\section{Water planning in the Azores and the Water Framework Directive}

The first stage of the AWP was a full diagnosis of the water resources status of the Azores. That assessment revealed that in general fresh water resources are of good quality and exceed by far water demand, despite both demand increases and the fact that in a few islands, like Graciosa and Santa Maria, groundwater abstraction is more complex and costly. The main weaknesses are related to eutrophication of surface water bodies and the insufficient territorial coverage of adequate sewage systems, which despite the improvement observed in the last decade is still insufficient, as only $46 \%$ of the population is actually covered by a waste water drainage system, with negative impacts on water quality [28, 29].

The AWP strategic guidelines were organized according to 9 thematic areas which are explained in Table $\mathbf{1}$.
In the same table, the interrelationship with the WFD objectives is presented, regarding their direct or indirect input toward a full implementation of the directive goals in the Azores.

For all AWP thematic areas, a total number of 20 programs, subdivided in 38 projects, were defined, for which more than 30 governmental organizations and municipalities were considered responsible. Other stakeholders included universities, research \& development institutes, private companies and non-governmental organizations (Table 2). The estimated investment reached $228 \mathrm{M} €$, about 940 $€ /$ inhabitant, mainly for the thematic areas related to water quality protection (40\%), water supply (32\%), natural and anthropogenic hazards (12\%) and natural resources $(9 \%)$.

\section{AWP IMPLEMENTATION ASSESSMENT}

\section{Methodology}

One of the key aspects of the AWP was the establishment of quantitative objectives, allowing an assessment of the implementation and results of the planned action programmes, and according to the Plan itself an evaluation should be made periodically. For that purpose, a set of 77 indicators was prepared according to a pressure-stateresponse model [30]. For thematic areas A1 to A4 pressure-state-response indicators were fully prepared, but for thematic areas A5 to A9 only response type indicators were used, as their respective programmes are instrumental toward improvements in thematic areas A1 to A3 (DROTRHINAG 2001) (Table 3)[15].

For the state and response indicators, goals for years 2006 and 2011 were defined considering measurements directly linked to work programmes. The year 2006 was selected because it corresponded to the end of an EU funding 
Table 2. AWP Programmes and Projects (DROTRH-INAG 2001)

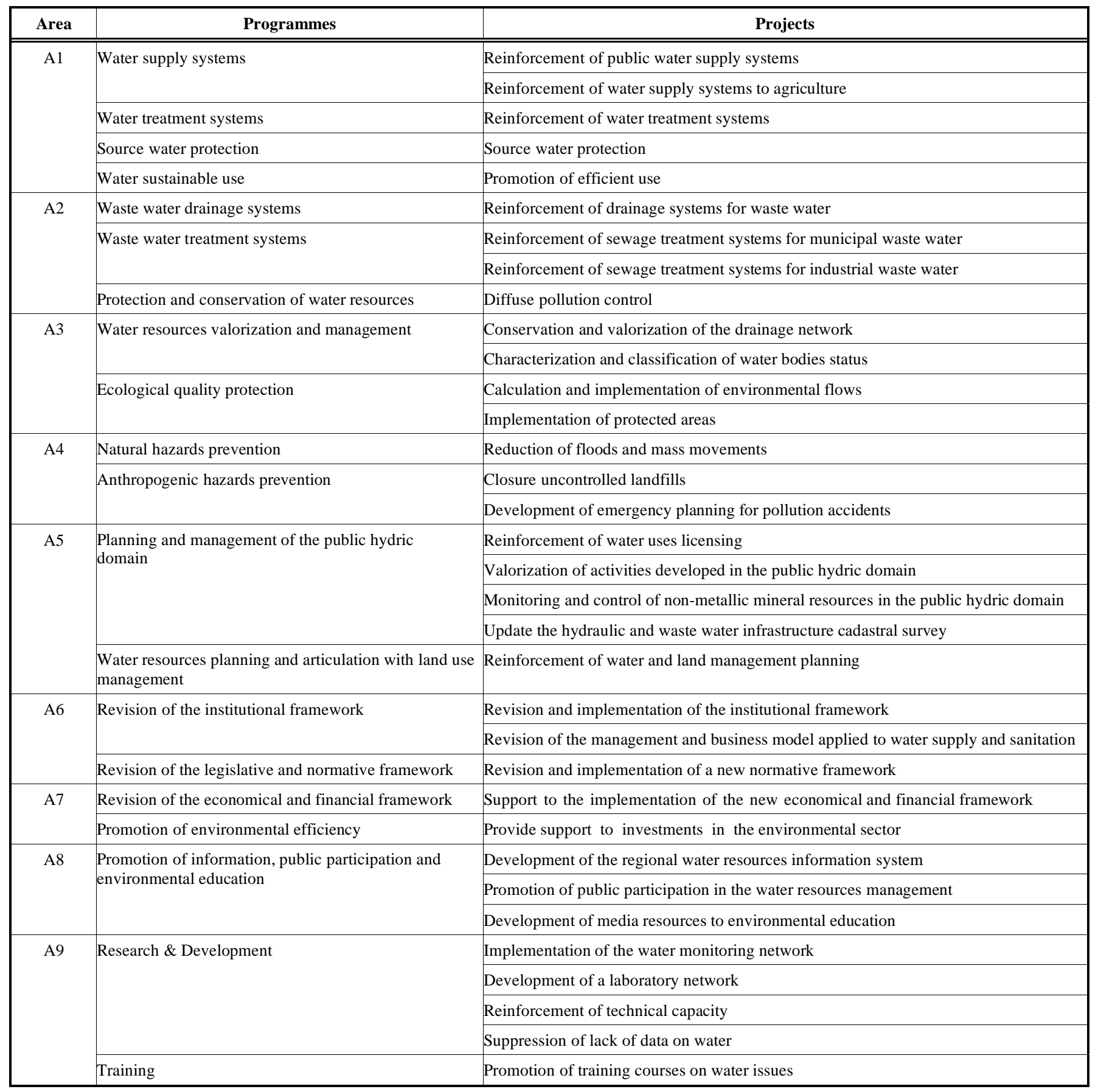

Table 3. Pressure-State-Response Indicators for Main Thematic Areas in the AWP (A1 to A4), and Selected Indicators for other Areas (a- Defined According to Legislation Applicable; CN - Normalized Number of Livestock Defined According to Age, Equal to 1 for a Cow with More Than 2 yr Old and 0.6 for a Animal 6 to 24 Months Old; p.e. - Population Equivalent as Defined by Directive $n^{\circ}$ 91/271/EEC; the INAG Surface Water Quality Indicator Considers 5 Categories from Non-Polluted - A- to Heavily Polluted Surface Waters - E). Source: DROTRH-INAG 2001

\begin{tabular}{|c|l|c|l|}
\hline Area & \multicolumn{1}{|c|}{ Pressure } & \multicolumn{1}{|c|}{ State } & \multicolumn{1}{|c|}{ Response } \\
\hline \hline \multirow{2}{*}{ A1 } & $\begin{array}{l}\text { A1.P1. Reserve exploitation (\%) } \\
\text { (Demand/available water ratio) }\end{array}$ & A1.S1. Water quality for urban supply (a) (\%) & A1.R1. Water sources protected (\%) \\
\cline { 2 - 3 } & $\begin{array}{l}\text { A1.P2. Water abstraction (\%) Groundwa- } \\
\text { ter/surface water }\end{array}$ & & $\begin{array}{l}\text { A1.R2. Dimension of water supply systems } \\
\text { (inhabitants) }\end{array}$ \\
\cline { 2 - 2 } & $\begin{array}{l}\text { A1 P3. Total water consumption } \\
(\mathrm{m} \text { /per capita.year) }\end{array}$ & A1.R3. Losses in water supply systems (\%) \\
\hline
\end{tabular}


Table 3. Cont....

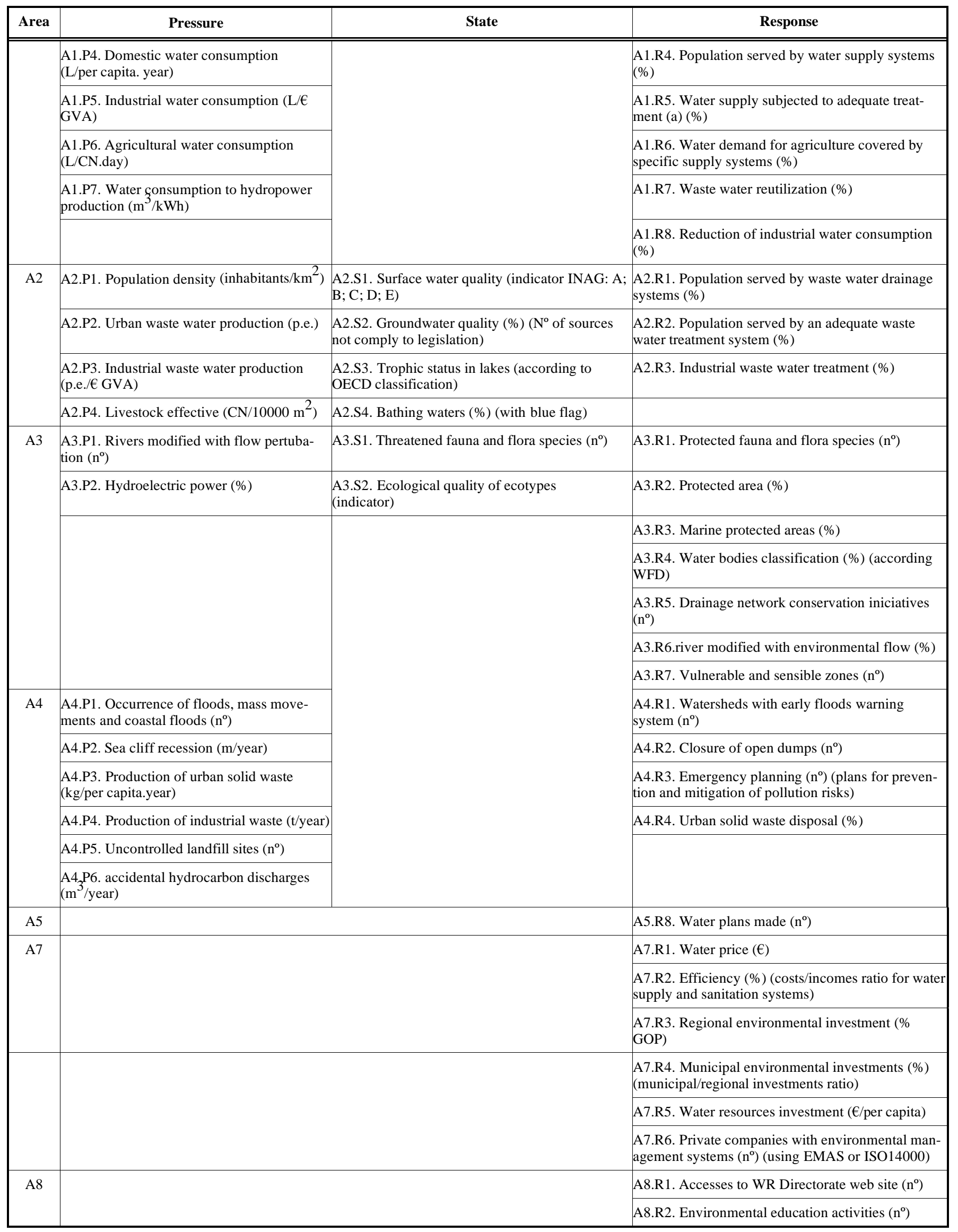


Table 3. Cont....

\begin{tabular}{|c|c|c|c|}
\hline Area & Pressure & State & Response \\
\hline & & & A8.R3. Environmental NGO's $\left(n^{\circ}\right)$ \\
\hline \multirow[t]{5}{*}{ A9 } & & & A9.R1. R \& D effort on water issues $(€)$ \\
\hline & & & A9.R2. $\mathrm{PhD}$ dissertations on water issues $\left(\mathrm{n}^{\circ}\right)$ \\
\hline & & & $\begin{array}{l}\text { A9.R3. Hydrometric network density }\left(\mathrm{n}^{\circ} / 1000 \mathrm{~km}^{2}\right) \\
\text { (automatic stations) }\end{array}$ \\
\hline & & & $\begin{array}{l}\text { A9.R4. Water supply quality monitoring }(\%)\left(\mathrm{n}^{\circ}\right. \\
\text { analysis/ } \mathrm{n}^{\circ} \text { analysis required by law ratio) }\end{array}$ \\
\hline & & & $\begin{array}{l}\text { A9.R5. Training courses on water issues }\left(n^{\circ}\right) \text { (orga- } \\
\text { nized by the government) }\end{array}$ \\
\hline
\end{tabular}

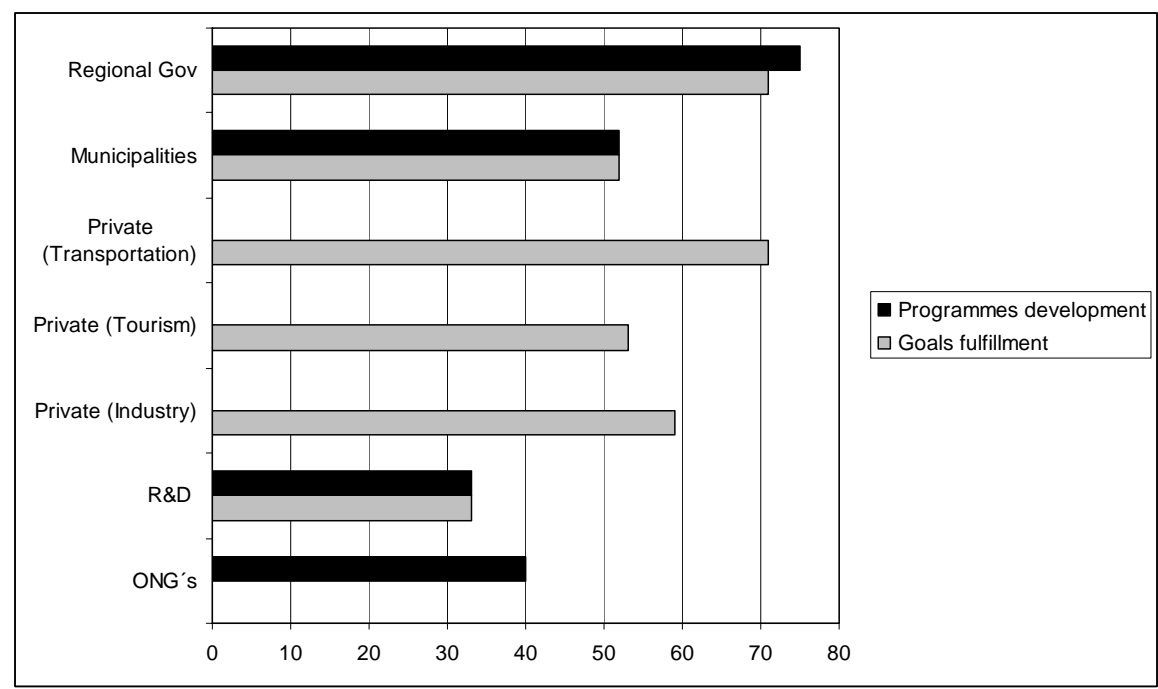

Fig. (2). Analysis of responses to enquiries according the type of organization involved in the AWP implementation (Regional Gov - Government of the Azores; Private - private companies; R\&D - Research \& Development organizations, including the Azores University and the Institute for Technological Innovation of the Azores; ONGs - Environmental non- governmental organizations).

cycle, and year 2011 as corresponds to the AWP implementation deadline.

The methodological approach was based on a consultation procedure involving all the organizations and stakeholders responsible for the AWP implementation, through the completion of enquiries specifically prepared to provide both (1) an assessment of the early diagnose made in 2000, providing an analysis of the evolution made since that year, according to the predefined set of indicators (equation 1), and (2) an evaluation of the development of all AWP programmes, through the assessment of the compliance with the specific objectives established in AWP (equation 2). The year 2005 was used as reference in the questionnaires, in order to warrant data availability.

Evolution $(\%)=\left(\mathrm{X}_{2005}-\mathrm{X}_{2000}\right) / \mathrm{X}_{2000 \times 100}$

In which: $X_{2005}$, value estimated for indicator in year 2005

$\mathrm{X}_{2000}$, value for indicator in AWP diagnostic

Compliance $(\%)=\mathrm{X}_{2005} / \mathrm{Goal}_{2006} \times 100$

(eq. 2)

In which:
$X_{2005}$, value estimated for indicator in year 2005

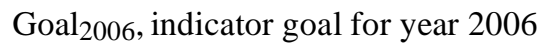

In order to facilitate consultation by the public a qualitative target scale was used, considering 3 categories: if the objective evaluation is lower than $50 \%$ is considered to be negative, intermediate if lies in the $50 \%$ to $80 \%$ interval and positive if higher than $80 \%$. It should be noted that the AWP implementation assessment is not based on the general trend depicted by data, but instead on the corresponding category in a proper magnitude scaling. Statistics bias or legislative changes are the reasons for such more robust methodology because they can undermine some observed trends (e.g. the monitoring standards regarding water quality were less stringent in 2000 than in 2006).

Regarding the evolution assessment, a total of 89 enquiries were submitted to institutions in different levels of government (regional and municipal), as well as private organizations and environmental non-governmental organizations (NGOs), from which a response rate of $56 \%$ was obtained. For the compliance assessment of the AWP programmes development, a total of 44 enquiries were submitted to all public and private institutions responsible for 
Table 4. Analysis of the Evolution Made Since 2005 According to the AWP Set of Indicators

\begin{tabular}{|c|c|c|c|c|c|c|c|c|c|}
\hline \multirow{2}{*}{ Area } & \multicolumn{3}{|c|}{ Pressure } & \multicolumn{3}{|c|}{ State } & \multicolumn{3}{|c|}{ Response } \\
\hline & Ind. & 2000 & 2005 & Ind. & 2000 & 2005 & Ind. & 2000 & 2005 \\
\hline \multirow{8}{*}{ A1 } & A1.P1 & $17 \%$ & $18 \%$ & A1.S1. & $80 \%$ comply & $93 \%$ comply & A1.R1 & $0 \%$ & $0 \%$ \\
\hline & A1.P2 & $\begin{array}{l}97 \% \mathrm{gw} \\
3 \% \mathrm{sw}\end{array}$ & $\begin{array}{l}99 \% \mathrm{gw} \\
1 \% \mathrm{sw}\end{array}$ & & & & A1.R2 & $\begin{array}{c}3900 \\
\text { inhabitant s }\end{array}$ & $\begin{array}{c}3612 \\
\text { inhabitant s }\end{array}$ \\
\hline & A1.P3 & $\begin{array}{c}60 \mathrm{~m}^{3} \text { /per cap- } \\
\text { ita.yr }\end{array}$ & $91 \mathrm{~m}^{3} /$ per capita.yr & & & & A1.R3 & $30 \%$ & $54 \%$ \\
\hline & A1.P4 & $\begin{array}{c}80 \mathrm{~L} / \text { per capita. } \\
\text { year }\end{array}$ & $\begin{array}{c}158 \mathrm{~L} / \text { per capita. } \\
\text { year }\end{array}$ & & & & A1.R4 & $87 \%$ & $98 \%$ \\
\hline & A1.P5 & $\begin{array}{c}0.33 \mathrm{~L} / € \\
\text { GVA }\end{array}$ & $\begin{array}{l}9.29 \mathrm{~L} / € \\
\text { GVA }\end{array}$ & & & & A1.R5 & $84 \%$ & $82 \%$ \\
\hline & A1.P6 & $\begin{array}{c}64 \\
\text { L/CN.day }\end{array}$ & n.a. & & & & A1.R6 & $<30 \%$ & n.a. \\
\hline & A1.P7 & $7.4 \mathrm{~m}^{3} / \mathrm{kWh}$ & $4.4 \mathrm{~m}^{3} / \mathrm{kWh}$ & & & & A1.R7 & $0 \%$ & $0 \%$ \\
\hline & & & & & & & A1.R8 & n.a. & n.a. \\
\hline \multirow{4}{*}{$\mathrm{A} 2$} & A2.P1 & $\begin{array}{l}103 \text { inhabitant/ } \\
\mathrm{km}^{2}\end{array}$ & 104 inhabitant $/ \mathrm{km}^{2}$ & A2.S1. & $2 \mathrm{~A}-8 \mathrm{~B}-7 \mathrm{C}$ & $2 \mathrm{~A}-8 \mathrm{~B}-7 \mathrm{C}$ & A2.R1 & $38 \%$ & $46 \%$ \\
\hline & A2.P2 & 95862 p.e. & 80959 p.e. & A2.S2. & $82 \%$ & $70 \%$ & A2.R2 & $22 \%$ & $35 \%$ \\
\hline & A2.P3 & $\begin{array}{c}\text { 0.002p.e./€ } \\
\text { GVA }\end{array}$ & $\begin{array}{c}\text { 0.001p.e./€ } \\
\text { GVA }\end{array}$ & A2.S3. & $7 \mathrm{E}-10 \mathrm{M}$ & $\begin{array}{l}\text { 8E-6M- } \\
\text { 1O-2n.a. }\end{array}$ & A2.R3 & $30 \%$ & n.a. \\
\hline & A2.P4 & $2.1 \mathrm{CN} / \mathrm{ha}$ & $1.5 \mathrm{CN} / \mathrm{ha}$ & A2.S4. & $56 \%$ & $46 \%$ & & & \\
\hline \multirow{7}{*}{ A3 } & A3.P1 & 29 & n.a. & A3.S1. & 320 & 70 & A3.R1 & 235 & 50 \\
\hline & A3.P2 & $4 \%$ & $7 \%$ & A3.S2. & $\begin{array}{l}4 \text { good to mod- } \\
\text { erate } 6 \text { moderate } \\
1 \text { moderate to } \\
\text { poor } 1 \text { bad } 4 \text { n.a. }\end{array}$ & $\begin{array}{l}16 \text { in risk } \\
1 \text { in doubt }\end{array}$ & A3.R2 & $23 \%$ & $16 \%$ \\
\hline & & & & & & & A3.R3 & $42 \mathrm{~km}^{2}$ & $48 \mathrm{~km}^{2}$ \\
\hline & & & & & & & A3.R4 & $0 \%$ & $100 \%$ \\
\hline & & & & & & & A3.R5 & n.a. & 203 \\
\hline & & & & & & & A3.R6 & $7 \%$ & n.a. \\
\hline & & & & & & & A3.R7 & 0 & 8 \\
\hline \multirow{6}{*}{ A4 } & A4.P1 & 0 & 0 & & & & A4.R1 & 0 & 0 \\
\hline & A4.P2 & 0.27 & 0.21 & & & & A4.R2 & 7 & 7 \\
\hline & A4.P3 & $0.6 \mathrm{t} /$ per capita.yr & $0.5 \mathrm{t} /$ per capita.yr & & & & A4.R3 & 3 & 19 \\
\hline & A4.P4 & $2768 \mathrm{t} / \mathrm{yr}$ & $14671 \mathrm{t} / \mathrm{yr}$ & & & & A4.R4 & $\begin{array}{l}54 \% \text { landfill; } \\
15 \% \text { sanitary } \\
\text { landfill; } 31 \% \\
\text { open dumps }\end{array}$ & $52 \%$ landfill \\
\hline & A4.P5 & 10 & 8 & & & & & & \\
\hline & A4.P6 & $160 \mathrm{t}$ & n.a. & & & & & & \\
\hline A5 & & & & & & & A5.R8 & 0 & 2 \\
\hline \multirow{7}{*}{ A7 } & & & & & & & A7.R1 & $0.48 € / \mathrm{m}^{3}$ & $0.67 € / \mathrm{m}^{3}$ \\
\hline & & & & & & & A7.R2 & $0.05 \%$ & n.a. \\
\hline & & & & & & & A7.R3 & $0,63 \%$ & $7 \%$ \\
\hline & & & & & & & A7.R4 & $48 \%$ & $84 \%$ \\
\hline & & & & & & & A7.R5 & $6 € /$ per & $80 € /$ per \\
\hline & & & & & & & & capita.yr & capita.yr \\
\hline & & & & & & & A7.R6 & 0 & n.a. \\
\hline
\end{tabular}


Table 4. cont....

\begin{tabular}{|c|c|c|c|c|c|c|c|c|c|}
\hline \multirow{2}{*}{ Area } & \multicolumn{3}{|c|}{ Pressure } & \multicolumn{3}{|c|}{ State } & \multicolumn{3}{|c|}{ Response } \\
\hline & Ind. & 2000 & 2005 & Ind. & 2000 & 2005 & Ind. & 2000 & 2005 \\
\hline \multirow{3}{*}{ A8 } & & & & & & & A8.R1 & 20 & 26 \\
\hline & & & & & & & A8.R2 & $<10$ & 5 \\
\hline & & & & & & & A8.R1 & 6 & 7 \\
\hline \multirow{5}{*}{ A9 } & & & & & & & A9.R1 & $212936 €$ & $83245 €$ \\
\hline & & & & & & & A9.R2 & 1 & 0 \\
\hline & & & & & & & A9.R3 & $0.4 / 1000 \mathrm{~km}^{2}$ & $1.3 / 1000 \mathrm{~km}^{2}$ \\
\hline & & & & & & & A9.R4 & $50 \%$ & $92 \%$ \\
\hline & & & & & & & A9.R5 & n.a. & $0.6 / \mathrm{yr}$ \\
\hline
\end{tabular}

Table 5. Assessment of the Compliance with the Specific Objectives Established in AWP, According to Goals Defined for Years 2006 and 2011 (Objective Performance: - Positive; $\square$ - Intermediate; $\bigcirc$ - Negative; n.a. - Data Not Available)

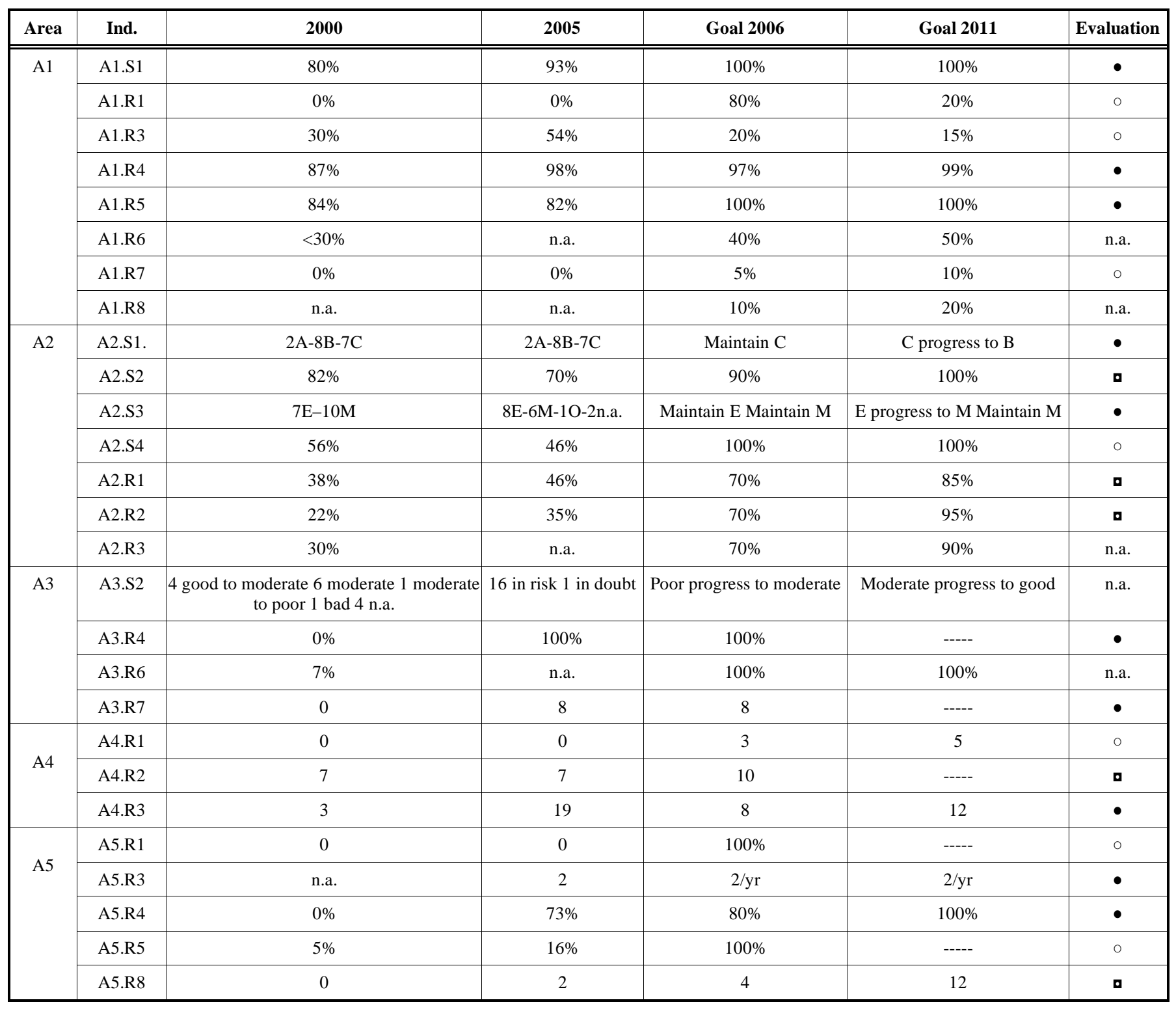


Table 5. cont....

\begin{tabular}{|c|c|c|c|c|c|c|}
\hline Area & Ind. & 2000 & 2005 & Goal 2006 & Goal 2011 & Evaluation \\
\hline \multirow{3}{*}{ A8 } & A8.R1 & 20 & 26 & 100/day & 300/day & o \\
\hline & A8.R2 & $<10$ & 5 & $12 / \mathrm{yr}$ & $18 / \mathrm{yr}$ & o \\
\hline & A8.R3 & 6 & 7 & $1 /$ island & $1 /$ island & - \\
\hline \multirow{2}{*}{ A9 } & A9.R4 & $50 \%$ & $92 \%$ & $100 \%$ & $100 \%$ & $\bullet$ \\
\hline & A9.R5 & n.a. & $0.6 / \mathrm{yr}$ & $1 / \mathrm{yr}$ & $1 / \mathrm{yr}$ & D \\
\hline
\end{tabular}

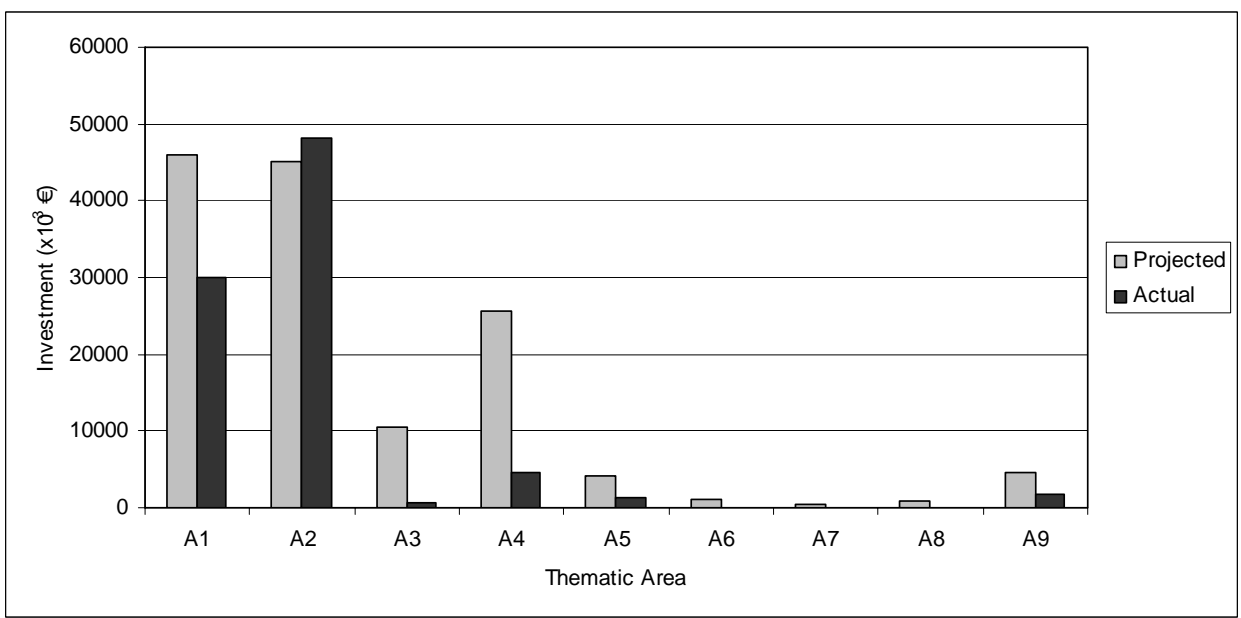

Fig. (3). Comparison between the actual investment made by all the organization involved in the AWP implementation and the expected investment associated to thematic areas of the AWP.

the development of the specific projects listed in the AWP, with a $55 \%$ response rate (Fig. 2).

The pool of 89 potential respondents was dominated by private companies in the fields of tourism $(31 \%)$, including golf courses, main industrial operations (19\%) such as dairy and fish cannery industries, transportation services (7\%), namely ports and airports, and utilities (1\%). Several directorates from the Azores government (13\%) were included, as well as municipalities (18\%), including municipal associations and autonomous water services providers. Environmental NGOs and Research \& Development organizations, such as the Azores University, represented respectively $4 \%$ each.

Prior to the enquiries submission, all respondents were visited in order to collect additional data, as well as to provide information about the methodology and objectives of the evaluation. All the enquiries had the same model, with three main sections, namely with questions about the respondent organization, including the identification of the person responsible for the enquiry, a main section about the specific contribution of the respondent and the collection of any additional information and suggestions. Nevertheless, facing the respondents diversity, all enquiries were prepared previously to the delivery considering the organizations characteristics and the expected role in the AWP implementation. The investment made by all parties was also computed and compared to the AWP prediction for each project.

\section{Results}

The methodology above described was applied in a study promoted by the Azores Government, in order to assess
AWP delivery, for which a consortium between universities and an environmental start-up was made.

Table 4 shows the results obtained through equation 1 (AWP diagnose reassessment), Results show that the development of the AWP is heterogeneous, with 11 objectives (34\%) been considered as positive, $7(21 \%)$ as intermediate and $9(27 \%)$ as negative. Table $\mathbf{5}$ depicts results from application of equation 2 (AWP objective development). From the AWP set a total of 6 were not evaluated mainly due to lack of data (Table 5).

From Table 4 is possible to show a general improvement in water management and protection in the Azores, as suggested by the comparison of AWP indicators in years 2000 and 2005. Although, some apparent incongruence in responses may arise, as in the example of indicator A1.R5, that suggests a decreasing trend in the drinking water treatment. Nevertheless, the increase on water abstraction and consumption observed in the same period (indicators A1.P2, A1.P3 and A1.P4) may explain the lower fraction of water submitted to proper treatment (Table 4) without necessarily compromising compliance to AWP objectives depicted in Table 5.

From the overall investment considered as necessary for a full development of the AWP in the studied period only $63 \%$ was actually made, showing also sharp differences when comparing data for the different thematic areas (Fig. 3).

Considering the most important thematic areas in what concerns financial obligations (A1 to A4; Table 1), is possible to notice that only for thematic area A2 the actual in- 
vestment was higher than the expected and only area A1 shows an actual value higher that $50 \%$ of the previewed. For thematic areas A3 and A8 the actual investment was lower than $10 \%$ of the projected amount and in the case of area A6 was absent.

\section{DISCUSSION}

The different degree of fulfilment of the objectives associate to the AWP implementation reflects closely the multi-level and multi-actor framework of the Plan. Through the close relationship between policy goals from AWP and the WFD (depicted in Table 1), the evaluation of the AWP delivery show consequences on the WFD implementation in the Azores.

The success of the AWP implementation, measured in the present work, through the analysis of the evolution and compliance of the several AWP goals, offers also as assessment of the WFD delivery in the Azores. Therefore, the major constrains and difficulties associated to AWP, and therefore WFD, implementation can be identified from results depicted in Tables 4 and 5, which are further discussed, especially in what concerns major areas as administration, financial framework, science and water policy relationship, monitoring and public participation which are further discussed.

Although not represented in Tables $\mathbf{4}$ and $\mathbf{5}$, as no specific indicators were provided in the AWP, not allowing further quantitative evaluation through equations 1 and 2, the establishment of the necessary institutional arrangements corresponds to the A6 thematic area (Table 1). Nevertheless, and despite only the qualitative evaluation, this AWP thematic area is identified as a constriction to a full AWP implementation, and is clearly associated to a major issue referred in the WFD, through the administration arrangements that should be made by all member states according to art. 3.

In accordance to the Portuguese law that proceed to the adaptation of the WFD, the Azores corresponds to a single river basin district, using the faculties to combine small river basins in larger units, facilitating water protection and management. Therefore, according to legislation, an administration for the Azores River Basin District should be created, but this task, as well as the revising of all associated normative framework, corresponding to AWP thematic area A6 (Table 1), has started only in 2007. Despite the fact that a polycentric governance system seems to be able to deliver more effective environmental outputs comparing to a model of monocentric governance [31], the objectives pursued by the administration are central toward the full WFD and AWP implementation, as water planning, management, monitoring and cost recovery, as well as will act as coordinator of multiple interventions made by public and private organizations, assuring the necessary degree of cooperation.

This explains the absence of investment made in A6 area, and triggered the deficit of coordination between all the responsible organizations for the development of the AWP programmes.

In the first stage of the WFD the regional government proceed to the identification of the competent authority for the Directive, naming the directorate-regional for land man-
Goals with positive evaluation

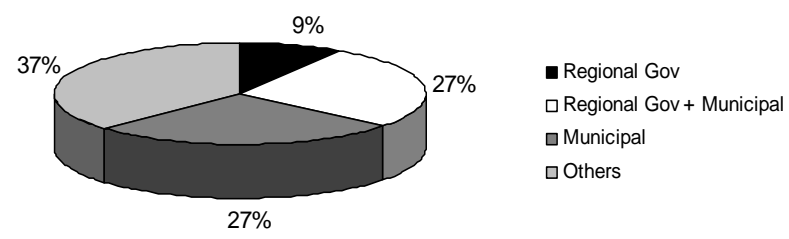

Goals with intermediate evaluation

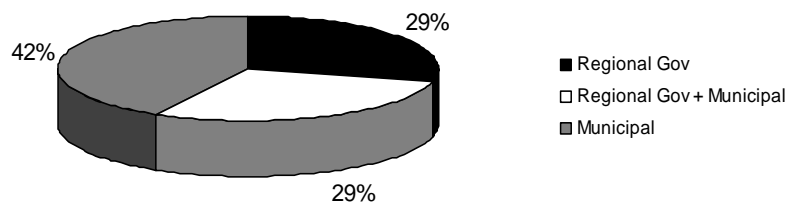

Goals with negative evaluation

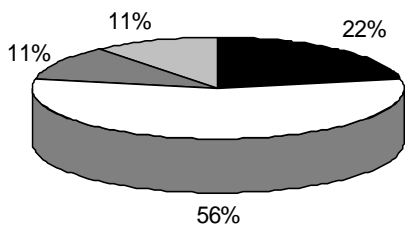

- Regional Gov $\square$ Regional Gov + Municipal 口unicipal $\square$ Others

Fig. (4). Analysis of AWP 2006 goals performance according the type of organization been responsible by the delivery.

agement and water resources (Regional Secretary for Environment and Sea), which was the organization responsible for the AWP preparation. Nevertheless, the future Azores River Basin District administration will be the competent authority. The two main issues been studied at the moment are the financial and human resources reinforcement of the referred water resources department or a new government level organization. Besides the solution to be adopted in the near future, the competent authority should be able to influence other parties responsible for the WFD implementation, in order to create and sustain a framework to promote coordination between stakeholders [32].

The effect of the actual coordination deficit at the Azores also explains that the major part of the goals which are classified as negative, according to their fulfilment, are to be implemented by both levels of public authorities $(56 \%)$, from the regional government and the municipalities, that should cooperate according to the AWP (Fig. 4). Even analysing the output of the programmes that are under the responsibility of different organizations from the regional government - from the environmental, agriculture and economic sectors - it becomes evident that the need for a cooperative action is strong, enabling the concentration of power and funding necessary to the implementation of the AWP and WFD. 
An example is the AWP source water protection programme (Table 2), as despite the fact that the government developed a study with the Azores University to proceed to delimitation of protection areas for groundwater sources, according to Portuguese law the municipalities are fully responsible for the water supply systems. Therefore, the implementation of the results of this study was not immediate and the 2006 AWP goal for water source protection valued as negative (Table 5).

An important fraction of the costs associated to WFD in the Azores lies in the regional government. This trend was usually observed in relation to previous water EU Directives, despite the fact that the amount of investment associated to the WFD implementation points out the need to proceed to costs outsourcing into the private sector [33].

The financial constriction is also usually associated with the AWP implementation. The financial obligations related with each programme exceed the budget of the public organizations been responsible by the delivery, as well as the financial support provided in the EU funds. As an example, the Directorate-Regional for Land Management and Water Resources, which is the main governmental authority responsible by the AWP and WFD implementation, had a total budget of about $58 \mathrm{M} €$ in the period 2001-2008, $51 \%$ of which was devoted to development of water policies.

Nevertheless, a considerable fraction of this budget was applied in the construction of costly coastal defence structures (about $13 \mathrm{M} €$ from 2000 to 2007) and not directly in the fulfilment of major issues in the AWP and WFD, and despite the annual budget increase observed since 2005, funding can be considered as largely insufficient for a full delivery of goals.

The investment made in AWP water quality thematic area (A2) will allow compliance according to the municipal waste water Directive, which was identified as a need by the European Commission in the analysis of the first stage of the WFD [10], but despite all the efforts made compliance with goals has yet to be achieved for the majority of the AWP objectives as indicators A2.R1 and A2.R2 are evaluated as intermediate (Table $\mathbf{5}$ ).

Forcing the efficient use of water and the protection of resources by water-pricing policies is also a fundamental guideline provided by the WFD, and also through the national adaptation [34]. Despite this fact, the related AWP thematic area A7 is one of the less successful, comprising only $40 \%$ of the AWP projected investment until 2005, and therefore the implementation of WFD article $9^{\text {th }}$ shows considerable delay (Table 5).

One key aspect of the WFD is the interrelationship between science and policy making process [35]. The complexity of the integration of science and the water policy has been shown since the development of the WFD itself as well as through the consultation process that has been conducted for the definition of the Common Implementation Strategy [36]. Several examples of the R\&D input can be drawn from the literature [37-40]. There was no evidence of using cost-effectiveness methodologies for applying AWP programmes, a subject where research is still going on at EU level.
Also in the AWP the interrelationship of science and water policy integration was considered to be the basis of thematic area A9 (Table 1). Results from this study shown that A9 objectives are classified from intermediate to positive (Table 5). These results reflects that research centres, mainly from universities, both in the Azores and the mainland, contribute actively whit the regional government in order to provide knowledge to AWP objectives compliance.

A thematic area of the AWP where the contribution of the scientific community has been most valuable corresponds to water bodies monitoring. Since the year 2003, a chemical and ecological monitoring network is operated in a close association between regional government and research centres, following the definition of a methodological approach adapted to regional hydrological characteristics. Data collected will also contribute to evaluate questions about the specificities associated to macaronesian fresh water biological communities, which have been suggested to justify an ecoregion [41].

Despite the financial demands, monitoring can be considered as one the most successful areas of the WFD implementation in the Azores, to which the AWP contributed decisively (Table 5). As monitoring can be considered as one of the most demanding areas of the WFD, as for example biological indicators require an higher effort and increasingly costs comparing to chemical parameters, the success of this task shows the advantage for the WFD implementation of small organizations, more able to tackle new approaches [1, 37]. Nevertheless, smaller organizations, as the Azores water resources department may not present enough power and funding to provide full leadership in a wider number of areas and to coordinate organizations from other levels of public intervention.

A new challenge is now foreseen in the Azores, as the quantitative monitoring of groundwater bodies, as well as coastal and transitional waters, demands investment. This investment is considered in the coastal management plans already prepared in the archipelago, and the first studies had started only in 2007.

The WFD, through art. 14 is extremely demanding in the public participation, in special what concerns to river basin plans, and opens a new window toward interactive water management, where the critical role of societal actors is widely recognized in the WFD governance-biased model [42]. Public participation has also motivated contributions from the scientific community [43].

The AWP also dedicates a thematic area to public participation (area A8; Table 1), but the evaluation of 2006 goals made in the present work showed a weak performance, as 2 objectives are considered to be negative and 1 intermediate (Table 5). Therefore this area demands a higher effort in order to fulfil the WFD objectives, as public involvement in water policy or management can add a surplus value to decision processes [44].

A set of 5 key indicators of the success of public participation [45]; scope of the participation, the effectiveness of communication, capacity building, timing and financing of the process. Considering these key issues, public participation in the Azores fails to achieve success in two of five of 
these criteria: insufficient capacity building due to lack of knowledge on the public and a common trend for an erroneous timing, as usually participation is envisaged at the end of the decision processes.

The development of WFD river basin plans, which in the Azores are to be made at the island scale in a first stage, followed by an archipelago integration scale, are the opportunity to proceed to the reversal of this trend. In fact the ruling provided by the WFD for the public involvement along the river basin plans is an opportunity to manage and even reduced uncertainties resulting from dual visions on goals and values [46].

The potential impact emerging from public participation was already characterized by Kastens and Newig (2007), in a case study related with agriculture impact over water quality [47]. In the Santa Maria case study, the first water resources management plan made at the island scale, an effort was made in order to fully identify all the stake holders and to get an early involvement through in-depth consultations, despite the low level of knowledge of the public [48].

A scale factor, common in other EU outermost archipelagic regions, favours the identification of stakeholders and the pursuit of an ideal timing for public participation. Other advantage is that in small communities, which like in the Azores archipelago suffered from a certain degree of isolation through centuries, is easier to identify societal values and local knowledge, and therefore to complement knowledge provided by experts and scientists involved in water resources management planning, which is more general in character [49].

The EU outermost strategy communications point out climate change as one process to which these regions are particularly vulnerable $[13,14]$. Therefore, as climate change should be considered as a risk to a cost-effective delivery of WFD objectives, the impact of this process should be fully investigated along side other pressures, which constitutes also a challenge in the near future at the Azores [50]. This task was not taken in consideration during the AWP preparation, which dates from 2001, and should be improved in a near reassessment.

As pointed out, the majority of the outermost regions are composed by islands and therefore issues related with the insular character of these regions constrain the WFD implementation. These main issues are related to geographic discontinuity, external isolation, scale, fragile environment and ecosystems, and socio-economic structural problems [51, 52]. In archipelagos, like Azores, each island corresponds to a particular ecosystem, internal and external isolated, evolving diversely over time. As a result, main problems associated to WFD implementation in the Azores are expected to occur in other outermost regions, which outline pathways for more comparative research on the subject. From our research, scale and financial support are the main difficulties to overcome in order to fulfil all WFD requirements, in the case of Azores through an effective AWP development.

\section{CONCLUSIONS}

Recognizing the socio-economic and environmental values of water resources in the Azores archipelago, subjected to an increasing pressure is last decades, the Regional Government of this autonomous region of the Portuguese Republic promote the AWP. The AWP which came to force in year 2003 provided a set of programmes in order to protect and enhance water resources in the Azores, developed according the WFD guidelines. Therefore, when evaluating the progresses made with AWP implementation indirectly is possible to draw some conclusions about the WFD implementation.

In order to assess the progresses made with the AWP implementation a consultation procedure involving all the organizations and stakeholders responsible for the AWP implementation was made, and despite the response level been about $50 \%$, in the majority of the cases it was possible to estimate values for a pre-defined set of 77 pressure-stateresponse indicators.

Results show that the development of the AWP is heterogeneous, with $11(34 \%)$ objectives been considered as positive, $7(21 \%)$ as intermediate and $9(27 \%)$ as negative. The delivery of the AWP objectives is constricted by several factors, been the most important the need to create and sustain a framework to promote coordination between stakeholders. For that the role of the Regional Government should be reinforced through the necessary administration arrangements, which should be made by all member states according to art. 3 of WFD.

The financial constriction is also usually associated with the AWP implementation, been a significant fraction of the costs lying in the regional government. Despite the increased observed since 2005, funding can be considered as largely insufficient for a full delivery of AWF goals. This question is of particular impact in the Azores, been a small EU outermost region and regarding the dispersion of the territory in nine islands.

The implementation of WFD art. 9 depict a considerable delay, but a cost-recovery policy will have to consider additional costs associated to territory dispersion, as water supply and sewage systems have to be implemented in islands where the number of inhabitants made difficult economic sustainability.

Monitoring can be considered as one the most successful areas of the WFD implementation in the Azores, to which the AWP contributed decisively, with a valuable contribution of the scientific community.

Through art. 14, WFD is extremely demanding in the public participation, but AWP implementation showed a weak performance on that subject. Therefore this area demands a higher effort in order to fulfil the WFD objectives and the development of river basin plans, which in the Azores are to be made at the island scale in a first stage, is an opportunity to reverse this trend.

The main constraints to overcome in order to fulfil the WFD requirements in the due time are associated to scale effect, especially in archipelagos made by small islands, that generally corresponds to physically-diverse settings, and to lack of a specific financial support. This financial support is extremely demanding due to the internal and external isolation of the outermost regions, requiring a closer attention by national and EU authorities. 
Our research suggests that water planning must be coupled with a set of implementation indicators, preferably also associated to WFD, in order to characterize delivery in the due time. This approach is rather important in the outermost regions, where WFD implementation is constrained by the specific factors already discussed.

\section{CONFLICT OF INTEREST}

None declared.

\section{ACKNOWLEDGEMENTS}

The authors wish to thank the two anonymous reviewers for the insight on an earlier version of this paper and for the comments which allow a major improve of the original manuscript.

\section{REFERENCES}

[1] Achleitner S, Toffol S, Engelhard C, Rauch W. The European Water Framework: water quality classification and implications to engineering planning. Environ Manage 2005; 35: 517-25.

[2] Moss B. The Water Framework Directive: total environment or political compromise. Sci Total Environ 2008; 400: 32-41.

[3] Kaika M. The Water Framework Directive: a new Directive for a changing social, political and economic European framework. Eur Plann Stud 2003; 11: 299-316.

[4] Kaika M, Page B. The EU Water Framework Directive: Part 1. European policy-making and the changing topography of lobbying. Eur Environ 2003; 13: 314-27.

[5] Moss T. The governance of land use in river basins: prospects for overcoming problems of institutional interplay with the EU Water Framework Directive. Land Use Policy 2004; 21: 85-94.

[6] Beunen R, van der Knaap W, Biesbroek G. Implementation and integration of EU environmental directives. Experiences from the Netherlands. Environ Policy Gov 2009; 19: 57-69.

[7] Narasimhan TN. Water, law, science. J Hydrol 2008; 349: 125-38.

[8] Costa S, Coutinho L, Nogueira R, et al. Cost-effectiveness analysis for sustainable wastewater engineering and water resources management: a case study at Minho-Lima's Rivers basins. Desalination Water Treat 2009; 4: 22-7.

[9] Fürhacker M. The Water Framework Directive - can we reach the target. Water Sci Tech 2008; 57: 9-17.

[10] CEC. Towards sustainable water management in the European Union. First stage in the implementation of the Water Framework Directive 2000/60/EC. COM (2007) 128 final, issued in $22^{\text {th }}$ March, EU Commission: Brussels 2007a.

[11] CEC. Analyse des regions insulaires et de régions ultrapériphériques de 1’Union européene. Partie I: Les territoires et les régions insulaires. Final report (prepared by Planistal Europe and Bradley Dunbar Associates Ltd), Contract $\mathrm{n}^{\mathrm{o}}$ 2000.CEE.16.0.AT.118, EU Commission: Brussels 2003a. (in French)

[12] CEC. Analyse des regions insulaires et de régions ultrapériphériques de 1'Union européene. Partie II: Les régions ultraphérifériques. Final report (prepared by Planistal Europe and Bradley Dunbar Associates Ltd), Contract $\mathrm{n}^{\circ}$ 2000.CEE.16.0.AT.118, EU Commission: Brussels 2003b. (in French)

[13] CEC. Strategy for the outermost regions: achievements and future prospects. COM (2007) 507 final, issued in $12^{\text {th }}$ September, EU Commission: Brussels 2007b.

[14] CEC. The outermost regions: an asset for Europe. COM (2008) 642 final, issued in $17^{\text {th }}$ October, EU Commission: Brussels 2008.

[15] DROTRH-INAG. Plano Regional da Água. Relatório técnico. Versão para consulta pública. DROTRH-INAG: Ponta Delgada 2001. (in Portuguese)

[16] Porteiro J. Lagoas dos Açores: elementos de suporte ao planeamento integrado. PhD dissertation. Ponta Delgada: Azores University 2000 (in Portuguese).

[17] Cruz JV, Antunes P, França Z, Nunes JC, Amaral C. Volcanic lakes from the Azores archipelago (Portugal): geological setting and geochemical characterization. J Volcanol Geotherm Res 2006; 156: $135-57$.
[18] Cruz JV, Silva MO. Hydrogeologic framework of the Pico island (Azores, Portugal). Hydrogeol J 2001; 9: 177-89.

[19] Cruz JV. Ensaio sobre a água subterrânea nos Açores. História, ocorrência e qualidade. SRA: Ponta Delgada 2004 (in Portuguese).

[20] Cruz JV. Salinization of the Basal Aquifer System at Volcanic Islands: Azores Archipelago (Portugal) Case Study. In: Ribeiro L, Ed. Proceedings $3^{\text {th }}$ International Conference on Future Groundwater Resources at Risk, June 25-27 2001; Lisbon: Portugal 2001.

Cruz JV, Amaral C. Major ion chemistry of groundwaters from perched-water bodies at Azores (Portugal) volcanic archipelago. Appl Geochem 2004; 19: 445-59.

[22] Cruz JV, Silva MO. Groundwater salinisation in Pico island (Azores, Portugal): origin and mechanisms. Environ Geol 2000; 39:1181-9.

[23] Santos MCR, Pacheco DM, Santana A F, Muelle H. Cyanobacteria blooms in Sete Cidades lake (São Miguel Island - Azores). Algol Stud 2005; 117: 393-406.

[24] Pacheco DM, Medeiros M, Santos MCR, Gonçalves V, Cruz JV. Desenvolvimentos Extremos de Cianobactérias na Lagoa das Furnas. Proceedings $9^{\circ}$ Congresso da Água; 2008April 2-4; Cascais, Portugal 2008 (in Portuguese)

[25] Martins G, Ribeiro D, Cruz JV, et al. Prospective scenarios for water quality and ecological status in Lake Sete Cidades (Portugal): the integration of mathematical modelling in decision processes. Appl Geochem 2008; 23: 2171-81.

[26] Ribeiro DC, Martins G, Nogueira R, Cruz JV, Brito AG. Phosphorus fractionation in volcanic lake sediments (Azores - Portugal) Chemosphere 2008; 70: 1256-63.

[27] DROTRH. Relatório síntese de caracterização da Região Hidrográfica, Arquipélago dos Açores, Portugal. DROTRH: Ponta Delgada 2006 (in Portuguese).

[28] Cymbron R, Pacheco D, Gonçalves V, et al. Monitorização da qualidade das águas superficiais das ilhas de Santa Maria e São Miguel da Região Autónoma dos Açores. Proceedings $8^{\circ}$ Congresso da Água, 2006 March 13-17; Figueira da Foz, Portugal 2006 (in Portuguese).

[29] DROTRH-INAG. Inventário nacional de sistemas de abastecimento de água e de águas residuais - INSAAR. Região Autónoma dos Açores. DROTRH-INAG: Ponta Delgada 2006. (in Portuguese)

[30] OECD. Toward sustainable development - environmental indicators. Paris: OECD Publications 1998.

[31] Newig J, Fritsch O. Environmental governance: participatory, multi-level and effective? Environ Policy Gov 2009; 19: 197-214.

[32] Green C, Fernández-Bilbao A. Implementing the Water Framework Directive: how to define a "competent authority". J Contemp Water Res Edu 2006; 135: 65-73.

[33] Page B, Kaika M. The EU Water Framework Directive: Part 2. Policy innovation and the shifting choreography of governance. Eur Environ 2003; 13: 328-43.

[34] Correljé A, François D, Verbeke T. Integrating water management and principles of policy: towards an EU framework? J Clean Prod 2007; 15: 1499-506.

[35] Mostert E. The European Water Framework Directive and water management research. Phys Chem Earth 2003a; 28: 523-7.

[36] Quevauviller P, Balabanis P., Fragakis C, et al. Science-policy integration needs in support of the implementation of the EU Water Framework Directive. Environ Sci Policy 2005; 8: 203-11.

[37] Dworak, T, Gonzalez C, Laaser C, Interwies E. The need for new monitoring tools to implement the WFD. Environ Sci Policy 2005; 8: 301-6.

[38] Videira N, Antunes P, Santos R, Lobo G. Public and stakeholder participation in European water policy: a critical review of project evaluation processes. Eur Environ 2006; 16: 19-31.

[39] Custodio E, Nieto P, Manzano M. Natural groundwater quality: policy considerations and european opinion. In: Edmunds WM Shand P, Eds. Natural groundwater quality. Malden: Blackwell Publishing 2008; pp. 178-94.

[40] Edmunds WM, Shand P. Natural groundwater quality - Summary and significance for water resources management. In: Edmunds WM, Shand P, Eds. Natural groundwater quality. Malden: Blackwell Publishing 2008; pp. 441-62.

[41] Hughes SJ. Application of the Water Framework Directive to macaronesian freshwater systems. Bio Environ Proc R Ir Acad 2005; 105B:185-93. 
[42] van Ast JA, Boot SP. Participation in European water policy. Phys Chem Earth 2003; 28: 555-62.

[43] Antunes P, Kallis G, Videira N, Santos R. Participation and evaluation for sustainable river basin governance. Ecol Econ 2009; 68: 931-9.

[44] Mostert E. The challenge of public participation. Water Policy 2004; 5: 179-97.

[45] Ozerol G, Newig J. Evaluating the sucess of public participation in water resources management: five key constituents. Water Policy 2008; 10: 639-65.

[46] Newig J, Pahl-Wostl C, Sigel K. The role of public participation in managing uncertainty in the implementation of the Water Framework Directive. Eur Environ 2005; 15: 333-43.

[47] Kastens B, Newig J. The Water Framework Directive and agricultural nitrate pollution: will great expectations in Brussels be dashed in Lower Saxony? Eur Environ 2007; 17: 231-46.
[48] DROTRH. Plano de gestão de recursos hídricos da ilha de Santa Maria. DROTRH: Ponta Delgada 2007 (in Portuguese).

[49] Hedelin B. Criteria for the assessment of processes for sustainable river basin management and their congruence with the EU Water Framework Directive. Eur Environ 2008; 18: 228-42.

[50] Wilby RL, Orr HG, Hedger M, Forrow D, Blackmore M. Risks posed by climate change to the delivery of Water Framework Directive objectives in the UK. Environ Int 2006; 32: 1043-55.

[51] Douglas CH. Small island states and territories: sustainable development issues and strategies - challenges for changing islands in a changing world. Sustain Dev 2006; 14: 75-80.

[52] Christofakis M, Mergos G, Papadaskalopoulos A. Sustainable and balanced development of insular space: the case of Greece. Sustain Dev 2009; 17: 365-77.

Received: June 22, 2011

Revised: December 23, 2011

Accepted: January 19, 2012

(c) Cruz et al.; Licensee Bentham Open.

This is an open access article licensed under the terms of the Creative Commons Attribution Non-Commercial License (http://creativecommons.org/licenses/by$\mathrm{nc} / 3.0 /$ ) which permits unrestricted, non-commercial use, distribution and reproduction in any medium, provided the work is properly cited. 